Esta revista forma parte del acervo de la Biblioteca Jurídica Virtual del Instituto de Investigaciones Jurídicas de la UNAM

\title{
LAS TRANSFORMACIONES JURÍDICO-POLÍTICAS DE LA GRAN BRETAÑA ¿CAMINO SIN RETORNO?*
}

\author{
GREAT BRITAIN LEGAL-POLITICAL TRANSFORMATIONS: \\ ONE WAY TRIP?
}

\section{Carlos Ruiz MigueL ${ }^{* *}$}

\begin{abstract}
RESUMEN: El sistema jurídico-político de la Gran Bretaña, el modelo parlamentario más antiguo, creado en el marco de una "Constitución” no escrita, ha experimentado desde 1972, fecha del ingreso en las comunidades europeas, profundas transformaciones que se han acelerado a raíz del anuncio de la salida del Reino Unido de la Unión Europea. Este proceso ha alterado el esquema de la distribución del poder con un fortalecimiento del Parlamento y de la Judicatura en detrimento del Ejecutivo. Cabe preguntarse si será reversible.
\end{abstract}

Palabras clave: derecho británico, derecho europeo, parlamentarismo, prerrogativa regia, jurisdicción.
ABSTRACT: The legal-political system of Great Britain, the oldest parliamentary model, created within the framework of an unwritten "Constitution", has undergone since 1972, the date it accessed the european communities, profound transformations that have accelerated following the announcement of the United Kingdom's withdrawal from the European Union. This process has altered the scheme of the distribution of power with a strengthening of the Parliament and the Judiciary to the detriment of the Executive. One may argue if there is a way back.

Keyzords: british law, european law, parlamentarism, royal prerrogative, jurisdiction.

SUMARIO: I. El modelo político británico clásico. II. Hitos en el rumbo reciente de la Gran Bretaña. III. Una revolución en el reparto del poder en el Reino Unido.

IV. Perspectivas en la organización del poder del sistema político británico.

Uno de los mejores conocedores del constitucionalismo británico que ha habido en la España del siglo XX, Teodoro González García, dio el título

* Recibido el 6 de enero de 2020; aprobado el 26 de noviembre de 2020.

** ORCID: 0000-0002-7001-7962. Catedrático de Derecho constitucional de la Universidad de Santiago de Compostela (España).Correo electrónico: carlos.ruiz@usc.es.

Boletín Mexicano de Derecho Comparado, nueva serie, año LIII, núm. 159, septiembre-diciembre de 2020, pp. 1181-1205. 
Esta revista forma parte del acervo de la Biblioteca Jurídica Virtual del Instituto de Investigaciones Jurídicas de la UNAM

de "El rumbo de la Gran Bretaña" a una de las cuatro obras que dedicó al tema (González García 1927, 1946, 1950, 1955). Teodoro González, que estudió durante decenios el sistema político inglés, reflexionaba en esa obra sobre el significado revolucionario que tenía la llegada al poder del Partido Laborista y el establecimiento del "Estado del bienestar" en el Reino Unido. Algunos decenios después, ese "Estado del bienestar" que transformó la Gran Bretaña que se convirtió en modelo político del Estado liberal se desmanteló parcialmente, pero la Gran Bretaña, lejos de volver a acercarse al modelo anterior experimentó nuevas transformaciones. Ese proceso se está acelerando en estos últimos años y ello nos obliga a plantearnos la misma cuestión que atrajo la atención de don Teodoro González: ¿cuál es el rumbo de la Gran Bretaña? ${ }^{1}$

\section{EL MODELO POLÍTICO BRITÁNICO CLÁSICO}

A veces se considera el modelo político británico como ejemplo de Constitución "histórica" (Sánchez Agesta 1968, 89) fruto de la "continuidad" del sistema político y como ejemplo de una "Constitución política" que no es una "Constitución jurídica". El sistema político británico aparece como un ejemplo de "Constitución flexible" donde no hay diferencia entre las "leyes constitucionales" y las otras leyes (Bryce 1901 vol. 1, 130, 133, 195). En ese modelo la soberanía se predica del Parlamento (Dicey 1885, 39-40), y no (o no directamente) del "pueblo". Al primer ministro se le atribuía la posibilidad de instar a la Corona a disolver la Cámara de los Comunes cuando considerara que la misma no reflejaba adecuadamente la voluntad de la ciudadanía o cuando "hubiese proyectado tomar una decisión grave (en el plano político o legislativo) y prefiriese interpelar en este aspecto al cuerpo electoral, utilizando las elecciones anticipadas como un referéndum" (Biscaretti 1996, 205-206).

Esta visión ha tenido, históricamente, algunos detractores. Quizá uno de los más importantes ha sido el profesor norteamericano John William

1 Este artículo tiene su origen en las reflexiones iniciales que publiqué con el título "El rumbo de la Gran Bretaña”, Razón Española 219: 53-61 (20202). Aquel texto, muy breve, y sin notas a pie de página ni bibliografía me incitó a profundizar en el problema de la transformación jurídico-política del Reino Unido. El presente texto es el resultado de ese esfuerzo.

Esta obra está bajo una Licencia Creative Commons

Atribución-NoComercial-SinDerivar 4.0 Internacional, IIJ-UNAM.

Boletín Mexicano de Derecho Comparado, núm. 159, septiembre-diciembre de 2020, pp. 1181-1205. 
Esta revista forma parte del acervo de la Biblioteca Jurídica Virtual del Instituto de Investigaciones Jurídicas de la UNAM

Burgess (1844-1931). Burgess considera la "Constitución de la Gran Bretaña" (adviértase que escribe antes de la formación del "Reino Unido de Gran Bretaña e Irlanda del Norte") como un producto con bastantes similitudes a las otras que estudia (Estados Unidos, Francia, Alemania). Burgess considera que el origen de la Constitución británica lejos de ser un producto de lenta decantación histórica nace, en realidad, como resultado de un proceso "revolucionario" en 1832 que constituye la tercera gran revolución inglesa después de las 1215 y 1485 (Burgess 1897, vol. 1, 118). No sólo eso, sino que el mismo Burgess ha defendido que Gran Bretaña tiene una "Constitución escrita" (Burgess 1897, vol. 1, 117), aunque no pueda dejar de reconocer que falta "una ley constitucional perfectamente separada de la legislación ordinaria" y que "es difícil distinguir con exactitud la legislación constitucional de la ordinaria" por lo que "falta por completo la piedra de toque jurídica” para hablar de Constitución (Burgess 1897, vol. 1, 170). En cualquier caso, este autor norteamericano, antes de la reforma de 1911, argumentó que en Gran Bretaña la Cámara de los Lores, en cuanto tribunal, constituía un "Tribunal Constitucional" partiendo de la premisa de considerar "tribunal constitucional" a aquel que tiene "el poder de impedir su abolición por una ley ordinaria", ya que "no puede adoptarse ninguna simple ley que afecte a sus facultades judiciales (de los Lores) sin su propio libre y consentimiento" (Burgess 1897, vol. 2, 379). Pero la reforma de 1911 (reforzada en 1949) eliminó el veto definitivo de la Cámara de los Lores, enervando así el argumento que daba Burgess.

\section{Hitos EN EL RUMBO RECIENTE DE LA GRAN BRETAÑA}

Las turbulencias producidas con la salida del Reino Unido de la Unión Europea han acelerado la profunda transformación que el sistema político inglés ha experimentado en las últimas décadas y que quizá ha sido una de las más profundas de su historia. Se puede discutir cual es la fecha relevante para entender el inicio de este proceso. Pero quizá se pueda decir que el hito inicial lo marca 1972 con la aprobación de la ley de ingreso en las Comunidades Europeas y el último hito (por el momento) lo constituye la sentencia del Tribunal Supremo británico del 24 de septiembre de 2019 en el caso Miller 2/Cherry. En este casi medio siglo ha habido una 
Esta revista forma parte del acervo de la Biblioteca Jurídica Virtual del Instituto de Investigaciones Jurídicas de la UNAM

concatenación de hechos que han ido marcando el rumbo (¿la deriva?) de la Gran Bretaña alterando de forma acusada la configuración jurídicopolítica anterior del país.

La primera fecha clave parece que podemos situarla el 17 de octubre de 1972, cuando gobernando el Partido Conservador, liderado por Edward Heath (primer ministro entre 1970 y 1974), se aprueba la "Ley de las Comunidades Europeas" "que introduce al Reino Unido en las Comunidades Europeas. Es importante advertir que cuando el Reino Unido se adhiere a las Comunidades, las mismas ya se habían configurado previamente como una comunidad supranacional por el Tribunal de Justicia de la Comunidad Europea a partir de las sentencias Van Gend $\mathcal{E}^{2}$ Loos $^{3}$ y Costa. ${ }^{4}$

2 European Communities Act 1972 (c 68), An Act to make provision in connection with the enlargement of the European Communities to include the United Kingdom, together with (for certain purposes) the Channel Islands, the Isle of Man and Gibraltar...

3 Sentencia del Tribunal de Justicia de la Comunidad Europea, Van Gend \& Loos, del 5 de febrero de 1963 (26/62): "los Estados han reconocido al derecho comunitario una eficacia susceptible de ser invocada por sus nacionales ante dichos órganos; que, por esas razones, ha de llegarse a la conclusión de que la Comunidad constituye un nuevo ordenamiento jurídico de derecho internacional, a favor del cual los Estados miembros han limitado su soberanía, si bien en un ámbito restringido, y cuyos sujetos son, no sólo los Estados miembros, sino también sus nacionales; que, en consecuencia, el derecho comunitario, autónomo respecto a la legislación de los Estados miembros, al igual que crea obligaciones a cargo de los particulares, está también destinado a generar derechos que se incorporan a su patrimonio jurídico".

4 Sentencia del Tribunal de Justicia de la Comunidad Europea, Costa c. ENEL, del 15 de julio de 1964 (6/64): "A diferencia de los Tratados internacionales ordinarios, el Tratado de la CEE creó un ordenamiento jurídico propio integrado en el sistema jurídico de los Estados miembros [...] y que vincula a sus órganos jurisdiccionales. Al instituir una comunidad de duración indefinida, dotada de instituciones propias, de personalidad, de capacidad jurídica, de capacidad de representación internacional, y más en particular, de poderes reales derivados de una limitación de competencia o de una transferencia de atribuciones de los Estados a la Comunidad, éstos han limitado su soberanía y han creado así un cuerpo normativo aplicable a sus nacionales y a sí mismos. De todo ello se desprende que al derecho creado por el Tratado, nacido de una fuente autónoma, no se puede oponer, en razón de su específica naturaleza original una norma interna, cualquiera que sea ésta, ante los órganos jurisdiccionales, sin que al mismo tiempo aquél pierda su carácter comunitario y se ponga en tela de juicio la base jurídica misma de la Comunidad [...] la transferencia realizada por los Estados, de su ordenamiento jurídico interno en favor del comunitario, de los derechos y obligaciones correspondientes a las disposiciones del Tratado, entraña por tanto una limitación definitiva de su soberanía, contra la que no puede prevalecer un acto unilateral ulterior incompatible con el concepto de Comunidad". 
Esta revista forma parte del acervo de la Biblioteca Jurídica Virtual del Instituto de Investigaciones Jurídicas de la UNAM

$\mathrm{Al}$ ratificar los tratados comunitarios y convertirlos en derecho interno, por primera vez en su historia, el Reino Unido incrustó una fuente del derecho, de origen internacional, por encima de las fuentes del derecho interno. ${ }^{5}$

Dada la resistencia que se había opuesto a esta integración, efectiva desde 1973, el gobierno laborista de Harold Wilson (primer ministro de 1974-1976) muy poco después de la adhesión a las Comunidades, promovió la aprobación, el 8 de mayo de 1975, de una ley que autorizó la celebración de un referéndum nacional, ${ }^{6}$ el primero en la historia del Reino Unido, para que el pueblo diera su opinión acerca de si el país debía seguir en las Comunidades Europeas o debía abandonarlas. No obstante, ese referéndum tenía un carácter consultivo, no vinculante. El referéndum, que se celebró el 5 de junio de 1975, arrojó un resultado favorable a la permanencia en las Comunidades Europeas.

Diecisiete años después de la adhesión a las Comunidades Europeas, el Tribunal de la Cámara de los Lores (en ese momento, el tribunal supremo del Reino Unido), en una decisión del 26 de julio de 1990 (Factortame 1) avaló que un tribunal británico pudiera dictar un auto aprobando como medida cautelar la inaplicación de una ley del Reino Unido ${ }^{7}$ que fuera contraria al derecho comunitario europeo. ${ }^{8}$ La decisión beneficiaba a una sociedad de pescadores españoles (Factortame) que operaban en aguas del Reino Unido y supuso la primera vez en la historia que un tribunal inglés ordenaba la no aplicación de una ley británica... si bien como aclaró el

5 (2017) UKSC 5, parágrafo 90 ("In 1972, for the first time in the history of the United Kingdom, a dynamic, international source of law was grafted onto, and above, the well-established existing sources of domestic law: Parliament and the courts").

6 Referendum Act 1975 (c 33): An Act to Provide for the Holding of a Referendum on the United Kingdom's Membership of the European Economic Community.

7 Merchant Shipping Act 1988 (c 12), An Act to amend the law relating to the registration of ships; to make provision for the giving of financial assistance in connection with the training of seamen and crew relief costs; to make provision for the establishment of a Merchant Navy Reserve; to make further provision with respect to the safety of shipping, with respect to liability and compensation for oil pollution and with respect to the financing and administration of the lighthouse service; to make other amendments of the law relating to shipping,seamen and pollution; and for connected purposes.

8 Regina $v s$. Secretary of State for Transport (Respondent) ex parte Factortame Limited and others (Appellants) (1990), 2 Lloyd's Rep 365 (1990), UKHL 7 (1990). 
Esta revista forma parte del acervo de la Biblioteca Jurídica Virtual del Instituto de Investigaciones Jurídicas de la UNAM

Tribunal de los Lores esto era consecuencia de aplicar la ley británica que incorporaba al Reino Unido a las Comunidades Europeas.

El 4 de mayo de 1979, el Partido Conservador de Margaret Thatcher (primera ministra de 1979 a 1990) se hizo con "Downing Street". Muy pronto Thatcher luchó para introducir correcciones en la situación del Reino Unido dentro de las Comunidades Europeas. Como consecuencia de ello, en 1984 consiguió la aprobación (en el "marco financiero plurianual") del "cheque británico" (UK rebate) mediante el que se devuelve al Reino Unido una parte sustancial de su aportación al presupuesto comunitario. No obstante, aunque Thatcher quisiera aparecer, o quieran hacerla aparecer, como la "campeona" de la lucha contra la burocracia de Bruselas, lo cierto es que en 1986 hizo que el "Acta Única Europea" se convirtiera en derecho británico. ${ }^{9}$ Fue precisamente esta "Acta Única Europea" una reforma de los tratados comunitarios que inició el camino hacia la transformación de las Comunidades en una unión política que más tarde, en 1992, dio un paso decisivo con la firma del Tratado de la Unión Europea, que fue transformado el año siguiente en derecho interno, ${ }^{10} \mathrm{con}$ el gobierno del primer ministro conservador John Major, que sucedió a Thatcher. El Tratado de la Unión Europea introdujo a las Comunidades Europeas en un proceso de integración política, además de profundizar en la integración económica y monetaria de la que Major dejó al margen al

9 European Communities (Amendment) Act 1986 (c 58), An Act to amend the European Communities Act 1972 so as to include in the definition of "the Treaties" and "the Community Treaties" certain provisions of the single European Act signed at Luxembourg and The Hague on 17th and 28th February 1986 and extend certain provisions relating to the European Court to any court attached thereto; and to amend references to the Assembly of the European Communities and approve the Single European Act.

10 European Communities (Amendment) Act 1993 (c 32): An Act to make provision consequential on the Treaty on European Union signed at Maastricht on 7th February 1992. El Reino Unido ratificó y convirtió en derecho interno las reformas subsiguientes: European Communities (Amendment) Act 1998 (c 21), An Act to make provision consequential on the Treaty signed at Amsterdam on 2nd October 1997 amending the Treaty on European Union, the Treaties establishing the European Communities and certain related Acts; European Communities (Amendment) Act 2002 (c 3), An Act to make provision consequential on the Treaty signed at Nice on 26th February 2001 amending the Treaty on European Union, the Treaties establishing the European Communities and certain related Acts; European Union (Amendment) Act 2008 (c 7), An Act to make provision in connection with the Treaty of Lisbon Amending the Treaty on European Union and the Treaty Establishing the European Community, signed at Lisbon on 13th December 2007. 
Esta revista forma parte del acervo de la Biblioteca Jurídica Virtual del Instituto de Investigaciones Jurídicas de la UNAM

Reino Unido. El hecho histórico es que, sin el voto favorable de Thatcher al Acta Única Europea, la Comunidad Europea nunca se habría convertido en la Unión Europea pues entonces, como ahora, se exige la unanimidad para la reforma de los tratados comunitarios. Cuestión distinta es la de si Thatcher dio su visto bueno a cambio de que no se le retirara el "cheque británico" conseguido en 1984 y cuya renovación dependía del acuerdo unánime de los Estados miembros; pero lo que es indudable es que esa Europa "federal" que ella denunciaba sólo se inició con su voto favorable al Acta Única Europea en 1986.

El gobierno laborista de Tony Blair (primer ministro de 1994 a 2007) ha sido quizá el que ha impulsado los cambios más profundos del sistema británico. En 1997 el Parlamento aprobó una ley para convocar sendos referendos en Escocia y Gales para introducir un régimen de autonomía en ambas naciones del Reino Unido. ${ }^{11}$ Los resultados favorables obtenidos en el referéndum de Escocia del 11 de septiembre de 1997 (74.29\% de votos favorables a la autonomía) y de Gales del 18 de septiembre de 1997 (50.30\% de votos favorables) condujeron a la aprobación de sendas leyes de otorgamiento ("devolution") de competencias a ambos territorios en 1998. ${ }^{12}$ Ese mismo año, además, el Parlamento británico aprobó, por primera vez, una verdadera declaración de derechos, al convertir el Convenio Europeo de Derechos Humanos (de 1950) en derecho interno británico mediante la "Ley de Derechos Humanos". ${ }^{13}$ Este Convenio no se elaboró en el marco de la Comunidad Europea/Unión Europea, sino

11 Referendums (Scotland \& Wales) Act 1997 (c. 61), An Act to make provision for the holding of a referendum in Scotland on the establishment and tax-varying powers of a Scottish Parliament and a referendum in Wales on the establishment of a Welsh assembly; and for expenditure in preparation for a Scottish Parliament or a Welsh Assembly.

12 Government of Wales Act 1998 (c. 38), An Act to establish and make provision about the National Assembly for Wales and the offices of Auditor General for Wales and Welsh Administration Ombudsman; to reform certain Welsh public bodies and abolish certain other Welsh public bodies; and for connected purposes; Scotland Act 1998 (c. 46), An Act to provide for the establishment of a Scottish Parliament and Administration and other changes in the government of Scotland; to provide for changes in the constitution and functions of certain public authorities; to provide for the variation of the basic rate of income tax in relation to income of Scottish taxpayers in accordance with a resolution of the Scottish Parliament; to amend the law about parliamentary constituencies in Scotland; and for connected purposes.

13 Human Rights Act 1998 (c 42), An Act to give further effect to rights and freedoms guaranteed under the European Convention on Human Rights; to make provision with 
Esta revista forma parte del acervo de la Biblioteca Jurídica Virtual del Instituto de Investigaciones Jurídicas de la UNAM

en el del Consejo de Europa y ha tenido un impacto político muy fuerte en el ordenamiento británico pues, entre otras cosas, ha significado privar al Poder Ejecutivo de competencias que hasta ahora ejercía en relación con ciertas autorizaciones para la entrada en domicilios o para intervenir comunicaciones. En virtud del Convenio Europeo, y de la ley británica que lo transforma en derecho interno, se transfiere al Poder Judicial la competencia de realizar esas intrusiones que, hasta entonces, ordenaba el Ejecutivo.

Un año después, en 1999, al tratar de nuevo el caso de la empresa pesquera española "Factortame", el tribunal supremo británico del momento, el Tribunal de la Cámara de los Lores, determinó que debía concederse a la empresa una indemnización por el daño que le causó la aplicación de una ley británica que era contraria al derecho comunitario europeo (caso Factortame 2), ${ }^{14}$ lo que constituyó una primicia en el derecho británico (García de Enterría 1998, 135).

Siete años después, el gobierno laborista de Tony Blair impulsó una profunda reforma con la "ley de reforma constitucional" del 24 de marzo de $2005^{15}$ que eliminaba la competencia judicial de los "lores jueces" de la Cámara de los Lores creando un órgano que en unos años estaría llamado a decidir cuestiones esenciales: el Tribunal Supremo del Reino Unido (United Kingdom Supreme Court, UKSC).

El 16 de febrero de 2011 se aprobó la ley sobre el sistema electoral (Ley sobre las Circunscripciones y el Sistema de Voto para Elegir el Parlamento), ${ }^{16}$ propuesta por el entonces viceprimer ministro, Nick Clegg,

respect to holders of certain judicial offices who become judges of the European Court of Human Rights; and for connected purposes...

14 Secretary of State for Transport, Ex Parte Factortame Ltd and Others, R v. (1999); UKHL 44 (2000); 1 AC 524 (1999); 4 All ER 906 (1999); 3 WLR 1062 (28th October 1999).

15 Constitutional Reform Act 2005 (c 4), An Act to make provision for modifying the office of Lord Chancellor, and to make provision relating to the functions of that office; to establish a Supreme Court of the United Kingdom, and to abolish the appellate jurisdiction of the House of Lords; to make provision about the jurisdiction of the Judicial Committee of the Privy Council and the judicial functions of the President of the Council; to make other provision about the judiciary, their appointment and discipline; and for connected purposes.

16 Parliamentary Voting System and Constituencies Act 2011 (c 1), An Act to make provision for a referendum on the voting system for parliamentary elections and to provide 
Esta revista forma parte del acervo de la Biblioteca Jurídica Virtual del Instituto de Investigaciones Jurídicas de la UNAM

del Partido de los Liberal-Demócratas, que gobernaba en coalición con el Partido Conservador liderado por David Cameron (primer ministro de 2010 a 2016). Esta ley sobre el sistema electoral preveía la convocatoria de un referéndum al que explícitamente se atribuía un efecto vinculante. Meses después, el 15 de septiembre, en una iniciativa impulsada también por el mismo líder liberal-demócrata, se aprobó la "Ley de las Legislaturas fijas del Parlamento" ${ }^{17}$ que privó al primer ministro de la competencia de disolver a su libre criterio la Cámara de los Comunes. Este cambio, que alteró sustancialmente la esencia del régimen parlamentario, se hizo sin respetar lo que alguna doctrina ha llamado "principio del mandato", que "sujeta la autoridad del Parlamento al voto de los electores, a los que se ha de consultar previamente a la aprobación de una ley que suponga una transformación del equilibrio de la Constitución inglesa" (Sánchez Agesta 1968, 101).

El 17 de diciembre de 2015, cuarenta años después del anterior, se aprobó por ley la convocatoria de otro referéndum sobre Europa, esta vez no sobre la salida de las Comunidades Europeas, sino sobre la salida de la Unión Europea ${ }^{18}$ y no bajo el gobierno de un primer ministro laborista, sino de uno conservador, David Cameron a la sazón. A diferencia del referéndum de 1975, que arrojó un voto favorable a las Comunidades Europeas, el de 2016, dio lugar a un pronunciamiento contra la Unión Europea por un estrecho margen (52\% frente al 48\%). Y a diferencia del de 1975, donde quedó explícitamente claro que se trataba de un referéndum consultivo, en el de 2016 la ley que autorizó el referendo guardó silencio sobre el efecto de éste.

Muy poco después del referéndum del "Brexit", el UKSG (creado en 2005, pero que empezó a funcionar en 2009) pronunció, el 24 de enero de 2017, su sentencia más importante hasta esa fecha: la llamada sentencia

for parliamentary elections to be held under the alternative vote system if a majority of those voting in the referendum are in favour of that; to make provision about the number and size of parliamentary constituencies; and for connected purposes.

17 Fixed-term Parliaments Act 2011 (c 14), An Act to make provision about the dissolution of Parliament and the determination of polling days for parliamentary general elections and for connected purposes.

18 European Union Referendum Act 2015 (c. 36), An Act to make provision for the holding of a referendum in the United Kingdom and Gibraltar on whether the United Kingdom should remain a member of the European Union. 
Esta revista forma parte del acervo de la Biblioteca Jurídica Virtual del Instituto de Investigaciones Jurídicas de la UNAM

"Miller-1". En esa sentencia el Tribunal Supremo tuvo que lidiar con la grave cuestión del efecto del referéndum del Brexit y resolvió que el gobierno no podía invocar el resultado del referéndum para decidir la salida del Reino Unido de la Unión Europea y que esa salida, que fue decidida por una ley del Parlamento, sólo podía operarse por otra ley del Parlamento. El principio de la "soberanía parlamentaria" encuentra su formulación clásica en el famoso tratadista del siglo XIX, Albert Venn Dicey, para quien "The principle of Parliamentary Sovereignty means neither more nor less than this, namely, that Parliament... has, under the English constitution, the right to make any law whatever; and, further, that no person or body is recognised by the law of England as having a right to override or set aside the legislation of Parliament" (Dicey 1885, 39-40). Este principio fue explícitamente reafirmado por el Tribunal Supremo en el caso Miller 1. ${ }^{19}$ Como consecuencia de esta sentencia, el Parlamento británico aprobó la "Ley (de Retirada) de la Unión Europea" que exigía que cualquier acuerdo (deal) de salida entre el gobierno británico y la Unión Europea debía ser aprobado por el Parlamento inglés. ${ }^{20}$

En un proceso de aceleración de los acontecimientos, el gobierno del primer ministro conservador, Boris Johnson (2019-), intentando llevar adelante el "Brexit" "duro" el 31 de octubre, en lugar de un "Brexit" "suave" con un acuerdo con la Unión Europea, tal y como era deseado por el Parlamento, decretó en agosto una inusual suspensión del Parlamento durante cinco semanas para intentar forzar a la Unión Europea a aceptar "su" Brexit planteando al Parlamento una situación de hechos casi consumados pues se establecía la apertura del nuevo periodo de sesiones el 17 de octubre, apenas dos semanas antes de concluir el plazo proyectado por el primer ministro para consumar "su" Brexit. Esta inusual medida fue recurrida ante los tribunales de Inglaterra y en Escocia que dictaron sentencias opuestas que, recurridas de nuevo ante el UKSC dieron lugar a una nueva, e importantísima, sentencia (la Miller-2/Cherry) que el 24 de

19 (2017) UKSC 5, R (on the application of Miller and another) (Respondents) v Secretary of State for Exiting the European Union (Appellant).

20 European Union (Withdrawal) Act 2018 (c 16), An Act to Repeal the European Communities Act 1972 and make other provision in connection with the withdrawal of the United Kingdom from the EU. 
Esta revista forma parte del acervo de la Biblioteca Jurídica Virtual del Instituto de Investigaciones Jurídicas de la UNAM

septiembre de 2019 declaró radicalmente nula la suspensión del Parlamento decretada por la reina a instancias del primer ministro. ${ }^{21}$

Por si fuera poco, además de las demandas ante los tribunales, el Ejecutivo se vio acorralado con la aprobación, el 9 de septiembre de 2019, de la llamada "ley Benn" (por el nombre de su impulsor, el diputado laborista Hillary Benn), que prohibió al Ejecutivo consumar el "Brexit" sin aprobación del Parlamento. Esta ley establecía que la salida del Reino Unido de la Unión Europea debía ser validada por el Parlamento, que debía aprobar tanto el eventual acuerdo con la Unión Europea para la salida, como una salida sin acuerdo. En caso de que el Parlamento no avalara la salida, el gobierno quedaba obligado a solicitar a la Unión Europea la prórroga de su presencia en la Unión Europea. ${ }^{22}$ Y así ocurrió, en efecto, el primer ministro Johnson envió el 19 de septiembre de 2019 una carta (sin firma) al presidente del Consejo Europeo (Donald Tusk) solicitándole una prórroga de la presencia del Reino Unido en la Unión Europea, expresando que lo hacía obligado por la ley británica, ${ }^{23}$ prórroga que fue concedida por la Unión Europea. ${ }^{24}$

\section{UNA REVOLUGIÓN EN EL REPARTO DEL PODER EN EL REINO UNIDO}

El proceso iniciado en 1972 se puede enfocar desde la perspectiva del reparto del poder en el Reino Unido. La situación, hasta ese momento, se podría definir como la de un régimen parlamentario que, teóricamente, proclamaba la soberanía del Parlamento, pero donde, en realidad, la

21 (2019) UKSC 41, R (on the application of Miller) (Appellant) v The Prime Minister (Respondent) Cherry and others (Respondents) v Advocate General for Scotland (Appellant) (Scotland), Miller 2/Cherry.

22 European Union (Withdrawal) (No. 2) Act 2019 (c. 26). An Act to make further provision in connection with the period for negotiations for withdrawing from the European Union.

23 Letters from the UK to the EU Council: 19 October 2019 https://assets.publishing. service.gov.uk/government/uploads/system/uploads/attachment_data/file/840665/Letter_from_UK_ to_EU_Council.pdf.

24 Decisión (UE) 2019/1810 del Consejo Europeo tomada de acuerdo con el Reino Unido de 29 de octubre de 2019 por la que se prorroga el plazo previsto en el artículo 50, apartado 3, del TUE. Diario Oficial de la Unión Europea LI 278/1, del 30 de octubre de 2019. https://eur-lex.europa.eu/legal-content/EN/TXT/?uri=CELEX:32019D1810. 
Esta revista forma parte del acervo de la Biblioteca Jurídica Virtual del Instituto de Investigaciones Jurídicas de la UNAM

soberanía se compartía con el Ejecutivo y donde los tribunales no podían controlar al Parlamento y tenían un papel muy limitado en el control de la actividad del Ejecutivo (la Corona y el Gabinete). Los cambios que se van a ir produciendo son: 1) el intento de relativización del Parlamento mediante la emergencia del poder popular por medio del referéndum; 2) el debilitamiento de la posición del Poder Ejecutivo (primero privándole de la libre decisión de disolver el parlamento, luego acotando sus competencias en política exterior y luego limitando el uso de la "prerrogativa" regia para suspender el parlamento, y 3 ) la emergencia de un Poder Judicial de mayor independencia y con crecientes competencias.

\section{Intento de relativización del poder del Parlamento por medio del referéndum}

El sistema político británico se basa en un principio fundamental: la soberanía del Parlamento, que de Lolme sintetizó en la famosa frase "el Parlamento inglés lo puede todo, excepto convertir a un hombre en mujer" ("Parliament can do every thing, except making a woman a man, or a man a woman") (De Lolme 1807, 132, en nota). Quienes aprobaron la convocatoria del referéndum de 1975 para cuestionar una decisión adoptada por el Parlamento en 1972 eran perfectamente conscientes de que un referéndum podía significar la aparición de un "poder popular" que, eventualmente, podría llegar a enfrentarse con el Parlamento que, hasta ese momento, era considerado doctrinalmente como "soberano". Para prevenir esa eventualidad se determinó previamente, con claridad, que el referéndum de 1975 no atribuía "poder" al pueblo, pues era un referéndum "consultivo" cuyo resultado no resultaba vinculante para el Parlamento. En todo caso, una vez que el referéndum avaló la ley de entrada en las Comunidades (Miller 2015, 25) no se produjo ningún tipo de conflicto entre la "voluntad popular" y el Parlamento.

Tres años después, el Parlamento británico por mayoría laborista aprobó sendas leyes relativas a Escocia y Gales que convocaban un referéndum vinculante bajo determinadas condiciones. Las leyes sobre Escocia de 1978 establecían que la efectividad de la atribución de un régimen de autonomía quedaba condicionada a que se celebrase un referéndum en el que triunfase el sí y al menos 40\% de los electores (que no de los vo- 
Esta revista forma parte del acervo de la Biblioteca Jurídica Virtual del Instituto de Investigaciones Jurídicas de la UNAM

tantes) apoyase dicha autonomía. ${ }^{25}$ Celebrados el 1o. de marzo de 1979 los referendos previstos, aunque en Escocia obtuvo un apoyo de $51.62 \%$ de los votantes, sólo representaban $32.9 \%$ de los electores, por lo cual el gobierno, habilitado por la ley, dictó una orden derogando la Ley de Autonomía. En Gales, por el contrario, 79.74\% de los votantes rechazó la autonomía. ${ }^{26}$ Casi 20 años después, en 1997, se convocaron nuevos referendos en Escocia y Gales a los que no se atribuyó efecto vinculante, y a los que ya nos hemos referido supra. ${ }^{27}$

En 2011 se volvió a convocar un nuevo referéndum, sobre el sistema electoral, que a diferencia del de 1975, fue vinculante y que, a diferencia de los de 1978 no condicionaban a una determinada magnitud de la mayoría el efecto vinculante de una eventual victoria del "sí". El carácter vinculante de este referéndum se estableció explícitamente en la ley que lo convocó (Ley sobre las Circunscripciones y el Sistema de Voto para Elegir el Parlamento). ${ }^{28}$

El problema que se planteó después, en la ley que convocó el referéndum de 2016, sobre la Unión Europea, es que a diferencia de lo establecido en la ley que convocó el referéndum sobre el sistema electoral o el de los referendos de Escocia y Gales, no se previó explícitamente que el resultado tuviera carácter vinculante. Sin embargo, el gobierno de la conservadora Theresa May intentó ejecutar el "Brexit" partiendo de la suposición de que, en caso de que nada se diga explícitamente, el referéndum debe tener un carácter vinculante. Esto suponía, nada más y nada menos, que

25 Scotland Act 1978 (c 51). An Act to provide for changes in the government of Scotland and in the procedure of Parliament and in the constitution and functions of certain public bodies. Section 85 .

Wales Act 1978 (c 52). An Act to provide for changes in the government of Wales and in the constitution and functions of certain public bodies. Section 80.

26 The Scotland Act 1978 (Repeal) Order 1979, No. 928. The Wales Act 1978 (Repeal) Order 1979, No. 933.

27 Referendums (Scotland \& Wales) Act 1997 (c. 61).

28 Parliamentary Voting System and Constituencies Act 2011 (c 1), Section 8: "(1) The Minister must make an order bringing into force section 9, Schedule 10 and Part 1 of Schedule 12 ("the alternative vote provisions") if-

(a) more votes are cast in the referendum in favour of the answer "Yes" than in favour of the answer "No" (...)

(2) If more votes are not cast in the referendum in favour of the answer "Yes" than in favour of the answer "No", the Minister must make an order repealing the alternative vote provisions". 
Esta revista forma parte del acervo de la Biblioteca Jurídica Virtual del Instituto de Investigaciones Jurídicas de la UNAM

alterar la naturaleza del sistema político británico para atribuir la soberanía al pueblo, en vez de al Parlamento. Frente a la decisión del gobierno de intentar proceder al "Brexit" sobre la base del mandato popular, ${ }^{29}$ una ciudadana llamada Gina Miller interpuso una demanda ante el Tribunal Divisional de Inglaterra y Gales, alegando que el proceder del Ejecutivo le privaba de los derechos que ahora le atribuyen las leyes que transforman los tratados comunitarios en derecho interno británico. El Tribunal de División de Inglaterra y Gales resolvió en favor de Miller, pero esta sentencia fue recurrida por el gobierno ante el UKSG y el Tribunal Supremo del Reino Unido en una importantísima sentencia del 24 de enero de 2017. En esta decisión, el Tribunal constató que tanto el Parlamento como el Ejecutivo habían admitido que, como consecuencia del principio de soberanía del Parlamento, los referendos son consultivos. ${ }^{30}$ El Tribunal precisamente recuerda que el principio de la soberanía del Parlamento es un principio "constitucional" fundamental, ${ }^{31}$ por lo que no es jurídicamente posible operar un "Brexit" sin que haya una ley del Parlamento que lo autorice.$^{32}$ De esta forma el UKSG, al menos de momento, ha frenado el intento del Ejecutivo de erosionar la posición del Parlamento atribuyendo al pueblo la soberanía que el sistema reconocía al Parlamento.

\section{Debilitamiento del Poder Ejecutivo}

Es curioso advertir que, mientras el Poder Ejecutivo se ha fortalecido en la mayor parte de los sistemas políticos democráticos occidentales (en el caso de España, de forma muy acusada), en el Reino Unido ha sufrido un debilitamiento, cuanto menos, formal. La posición del Poder Ejecutivo en las últimas décadas se ha visto degradada por dos fenómenos, por un lado, al privarle de la libre decisión de disolver el Parlamento, luego

29 (2017) UKSC 5, Miller 1, para. 2 ("The particular issue is whether a formal notice of withdrawal can lawfully be given by ministers without prior legislation passed in both Houses of Parliament and assented to by HM The Queen”).

30 (2017) UKSC 5, Miller 1, parágrafo 25.

31 (2017) UKSC 5, Miller 1, parágrafo. 47.

32 (2017) UKSC 5, Miller 1, para. 121 ("Where, as in this case, implementation of a referendum result requires a change in the law of the land, and statute has not provided for that change, the change in the law must be made in the only way in which the UK constitution permits, namely through Parliamentary legislation”).

Esta obra está bajo una Licencia Creative Commons

Atribución-NoComercial-SinDerivar 4.0 Internacional, IIJ-UNAM.

Boletín Mexicano de Derecho Comparado, núm. 159, septiembre-diciembre de 2020, pp. 1181-1205. 
Esta revista forma parte del acervo de la Biblioteca Jurídica Virtual del Instituto de Investigaciones Jurídicas de la UNAM

acotando competencias en política exterior y luego limitando el uso de la "prerrogativa" regia para suspender el Parlamento.

El fenómeno que llama más poderosamente la atención es el hecho de que el país que fue cuna del régimen parlamentario lo haya desnaturalizado al eliminar uno de los dos pilares de éste. El sistema parlamentario se construye, fundamentalmente, sobre la premisa de que el jefe del Ejecutivo necesita la confianza del Parlamento. Cuando esa confianza se rompe se considera necesario restablecerla de dos posibles modos: o bien el primer ministro es destituido por el Parlamento, o bien el primer ministro disuelve el Parlamento. Parafraseando el escenario de la bomba atómica estamos ante un "equilibrio del terror". Sin embargo, la "Ley de las Legislaturas Fijas del Parlamento", de septiembre de 2011, impulsada por el Partido de los Liberal-Demócratas, entonces gobernando en coalición con los conservadores, rompió ese equilibrio debilitando al primer ministro. A raíz de la aprobación de esa ley, el primer ministro ya no puede disolver la Cámara de los Comunes por su sola decisión y sólo puede hacerlo si, previamente, la Cámara se lo permite por una mayoría de $2 / 3 .{ }^{33}$ La inercia en la consideración del Reino Unido como "modelo del parlamentarismo" lleva a pasar por alto un cambio tan trascendental en una obra de referencia en México que, un año después de haberse aprobado esta ley, seguía insistiendo en que el Reino Unido mantiene los elementos básicos de un régimen parlamentario ortodoxo, como el derecho del primer ministro (formalmente, prerrogativa regia) de disolución de la Cámara de los Comunes (Fix-Zamudio y Valencia Carmona 2012, 321, 325, 326). ${ }^{34}$

Otro de los hechos que ha debilitado la posición del Ejecutivo fue el osado intento de actuar en política europea buscando una habilitación jurídica en el resultado del referéndum del "Brexit". La sentencia del UKSG, del 24 de enero de 2017, en el caso "Miller-1" cortó en seco esa

33 Fixed-term Parliaments Act 2011 (c 14), Section 2 “(1) An early parliamentary general election is to take place if - (...) (b) if the motion is passed on a division, the number of members who vote in favour of the motion is a number equal to or greater than two thirds of the number of seats in the House (including vacant seats)".

34 Estas afirmaciones desactualizadas se contienen en la 8a. ed., de 2012, de la monumental obra de estos dos autores. Sin embargo, no hemos podido comprobar si se mantienen en la 9a. ed. de 2017. Debe advertirse, en todo caso, que esta 8 a edición seguía, en 2012, refiriéndose a la "victoria laborista" en "las recientes elecciones de 1997" (p. 332) sin tomar en cuenta las elecciones de 2010 que habían ya sido ganadas, sin mayoría absoluta, por los conservadores, que gobernaron junto a los liberal-demócratas. 
Esta revista forma parte del acervo de la Biblioteca Jurídica Virtual del Instituto de Investigaciones Jurídicas de la UNAM

pretensión al afirmar que la decisión de salir de la UE sólo podía ser tomada por el Parlamento, pues fue el Parlamento quien adoptó la decisión de entrar. El UKSC resolvió el intento del gobierno de enfrentar al Parlamento con el pueblo, reafirmando la posición del gobierno y acotando la del Gabinete.

El último y más dramático episodio ha sido la orden real dictada por la reina Isabel II, siguiendo el "consejo" del primer ministro conservador, Boris Johnson, de ordenar una suspensión del Parlamento de una duración inusual: cinco semanas, en lugar de la habitual de cinco o siete días. El objetivo político de esta medida era impedir el control del Parlamento que, en relación con el "Brexit" mantenía una posición mayoritaria opuesta a la que mantenía el primer ministro. Sin la oposición del Parlamento, el primer ministro pretendía tener manos libres para llevar a cabo su estrategia para consumar el "Brexit" poniendo al Parlamento ante una situación de prácticamente hechos consumados, pues el Parlamento sólo volvería a reunirse el 17 de octubre de 2019, apenas dos semanas antes de concluir la prórroga pactada entre el Reino Unido y la Unión Europea para proceder a un "Brexit" con un acuerdo (deal). Para conseguir ese objetivo, el primer ministro apeló a la "prerrogativa real", el poder del rey heredado del pasado y considerado hasta entonces como inmune a la jurisdicción.

Frente a esta orden real de suspensión se presentaron sendas demandas, una en Escocia, por la diputada nacionalista escocesa Joanna Cherry y otros, la otra demanda, en Londres, por Gina Miller, la misma que en 2016 cuestionó la política del gobierno ganando el caso ante el UKSC. En Escocia, el Tribunal Superior estimó la demanda de Cherry y sentenció que la real orden de suspensión del Parlamento era radicalmente nula, mientras que el Tribunal de Londres, que conoció de la demanda de Miller en primera instancia, consideró que esa misma orden era conforme al ordenamiento. Ambas sentencias fueron recurridas ante el UKSG que en una sentencia trascendental determinó que los tribunales, si bien no pueden enjuiciar la oportunidad o el contenido político del uso de la prerrogativa, sí pueden determinar si se ha abusado de la prerrogativa para hacerla llegar más allá de donde está jurídicamente permitido. De esta forma, el Tribunal Supremo ha establecido que la prerrogativa, a partir de ahora, no es una "patente de corso" y que su uso es nulo si vulnera dos principios "constitucionales" fundamentales que son el de la "soberanía 
Esta revista forma parte del acervo de la Biblioteca Jurídica Virtual del Instituto de Investigaciones Jurídicas de la UNAM

del Parlamento"35 y el de la "obligación de que el Ejecutivo sea responsable ante el Parlamento". ${ }^{36}$ Así pues, la política aventurera del Gabinete ha tenido como resultado la sentencia en el caso Miller 2/Cherry que ha sometido la "prerrogativa" real al control judicial.

\section{Emergencia de un Poder Fudicial de mayor independencia $y$ con crecientes competencias}

Creo que no sería exagerado decir que en el sistema jurídico-político británico "ha nacido una estrella", que no es otra que el UKSC. Este tribunal, creado en 2005 y que echó a andar en 2009, en sus primeros diez años de vida ha dictado dos sentencias que son fundamentales para definir el sistema político británico (la "Miller 1" y la "Miller 2/Cherry"). Hay, a mi juicio, dos elementos que explican el papel que ha adquirido el Tribunal Supremo. El primero, y no poco relevante, es que el modo de selección de los miembros del Tribunal garantiza una independencia mucho mayor de la que tenían los "Lores jueces" de la Cámara de los Lores. El segundo es que, precisamente por ser un órgano nuevo, ha aprovechado estos casos para afirmar su posición en el sistema. La novedad del órgano se ha hecho notar incluso simbólicamente, y se advierte en que, a diferencia de los "Lores jueces", los magistrados del UKSG no usan peluca ni visten las togas que usaban sus predecesores.

No obstante, lo anterior, conviene matizar. Como antes se dijo, fue el Tribunal de los Lores quien, en 1990 y por primera vez en la historia británica, consideró lícito no aplicar una ley del Parlamento si era contraria al derecho comunitario europeo. No sólo eso, sino que fue ese mismo Tribunal de los Lores quien consideró apropiado indemnizar a un particular por los daños sufridos por la aplicación de una ley del Parlamento británi-

35 (2019) UKSC 41, Miller 2/Cherry, parágrafo 41 ("Time and again, in a series of cases since the 17 th century, the courts have protected Parliamentary sovereignty from threats posed to it by the use of prerogative powers, and in doing so have demonstrated that prerogative powers are limited by the principle of Parliamentary sovereignty"); 42 ("An unlimited power of prorogation would therefore be incompatible with the legal principle of Parliamentary sovereignty").

36 (2019) UKSC 41, Miller 2/Cherry, parágrafo 48 ("the longer that Parliament stands prorogued, the greater the risk that responsible government may be replaced by unaccountable government: the antithesis of the democratic model"). 
Esta revista forma parte del acervo de la Biblioteca Jurídica Virtual del Instituto de Investigaciones Jurídicas de la UNAM

co que era contraria al derecho comunitario. Y aunque, ciertamente, esa inaplicación de una ley del Parlamento se justificaba en el hecho de que ello era consecuencia de la aplicación de otra ley del Parlamento (la ley que incorporaba al Reino Unido a las Comunidades Europeas), el hecho es que fue el muy tradicional Tribunal de los Lores, y no el muy reciente Tribunal Supremo del Reino Unido, quien por primera vez en la Historia autorizó la inaplicación de una ley británica.

Aunque una opinión superficial puede ver en este Tribunal Supremo un "Tribunal Constitucional" esto debiera matizarse. En primer lugar, aunque el Tribunal haya decidido sus más importantes sentencias invocando "principios constitucionales", en el Reino Unido no existe una "Constitución" escrita. La norma suprema, y así lo reconoce el Tribunal Supremo, es la ley. Ninguna norma está por encima de la ley del Parlamento, y en ese sentido, a diferencia de lo que ocurre con los tribunales constitucionales típicos, el Tribunal Supremo británico no tiene competencia, ni es previsible que la vaya a tener, para controlar y, eventualmente, anular leyes del Parlamento. Ahora bien, el sistema político británico tenía, al menos hasta ahora, un débil sistema de control judicial frente a lo que García de Enterría llamó "las inmunidades del poder en el derecho administrativo" (García de Enterría 1962). La "prerrogativa real" se erigía como un "acto político" al margen del Parlamento, no era un "acto jurídico", por tanto, no era un "acto administrativo" y en consecuencia no era susceptible de control judicial. El UKSG está llevando a cabo en el Reino Unido, respecto al Ejecutivo, algo parecido a lo que hizo la Sala de lo Contencioso-Administrativo del Tribunal Supremo español desde finales de los años cincuenta del siglo XX: recortar el ámbito del "acto político" (las political questions del derecho británico) para "administrativizar" el Poder Ejecutivo y poderlo así someter al control judicial.

\section{La construcción jurisprudencial de la categoría de las "leyes constitucionales"}

Como ha indicado Vírgala, desde 2002, la jurisprudencia de los tribunales británicos ha construido la categoría "legislación constitucional" británico como categoría formalmente diferente de la "legislación ordinaria" (Vírgala 2019, 128-138, 146). Es importante advertir que la categoría de la "legislación constitucional" (Constitutional Statute) fue construida 
Esta revista forma parte del acervo de la Biblioteca Jurídica Virtual del Instituto de Investigaciones Jurídicas de la UNAM

en una sentencia de 2002 (el caso Thoburn) por Lord Laws para intentar dar una coherencia a la inserción del derecho comunitario europeo (dotado de "primacía" sobre el derecho nacional) en un ordenamiento, el británico, presidido por el principio de la "soberanía parlamentaria". ${ }^{37}$ La jurisprudencia ha intentado construir la categoría de la "legislación constitucional" con un contenido material específico y una singularidad formal. Materialmente, una "ley constitucional" es descrita como aquella que: o bien a) regula las condiciones de la relación jurídica entre el ciudadano y el Estado de un modo general o b) amplía o restringe el alcance de lo que se podría considerar los "derechos constitucionales fundamentales". El estatus especial otorgado a las "leyes constitucionales" derivaría del especial estatus de los "derechos constitucionales". ${ }^{38}$ Formalmente, la sentencia Thoburn configura las "leyes constitucionales" como aquellas que sólo pueden ser derogadas por una declaración explícita e inequívoca del Parlamento, a diferencia de las "leyes ordinarias" que pueden ser derogadas de forma implícita. ${ }^{39}$ La conclusión es que la "Ley de las Comu-

37 (2002) EWHC 195 (Admin), Thoburn v. Sunderland City Council, del 18 de febrero de 2002, parágrafo 60 ("the courts have found their way through the impasse seemingly created by two supremacies, the supremacy of European law and the supremacy of Parliament").

38 (2002) EWHC 195 (Admin), Thoburn v. Sunderland City Council, parágrafo 62 ("ordinary" statutes and "constitutional" statutes. The two categories must be distinguished on a principled basis. In my opinion a constitutional statute is one which (a) conditions the legal relationship between citizen and State in some general, overarching manner, or (b) enlarges or diminishes the scope of what we would now regard as fundamental constitutional rights. (a) and (b) are of necessity closely related: it is difficult to think of an instance of (a) that is not also an instance of (b). The special status of constitutional statutes follows the special status of constitutional rights. (...) The ECA clearly belongs in this family. It incorporated the whole corpus of substantive Community rights and obligations and gave overriding domestic effect to the judicial and administrative machinery of Community law. It may be there has never been a statute having such profound effects on so many dimensions of our daily lives. The ECA is, by force of the common law, a constitutional statute).

39 (2002) EWHC 195 (Admin), Thoburn v. Sunderland City Council, parágrafo 63 ("Ordinary statutes may be impliedly repealed. Constitutional statutes may not. For the repeal of a constitutional Act or the abrogation of a fundamental right to be affected by statute, the court would apply this test: is it shown that the legislature's actual - not imputed, constructive or presumed - intention was to affect the repeal or abrogation? I think the test could only be met by express words in the later statute, or by words so specific that the inference of an actual determination to affect the result contended for was irresistible. The ord The ECA is a constitutional statute: that is, it cannot be impliedly repealed inary rule of 
Esta revista forma parte del acervo de la Biblioteca Jurídica Virtual del Instituto de Investigaciones Jurídicas de la UNAM

nidades Europeas" de 1972 mediante la que el Reino Unido incorporó el derecho comunitario europeo era una "ley constitucional" que sólo podía ser derogada explícitamente. ${ }^{40}$

La construcción de la sentencia Thoburn tiene, en mi opinión, notorias debilidades. Por un lado, la consideración "material" de las "leyes constitucionales" se construye sobre un deficiente razonamiento lógico pues trata de definir como "constitucionales" las leyes que tratan de derechos "constitucionales" ...pero "olvidando" que en ninguna ley del Parlamento se definen derechos "constitucionales". Por otro, la consideración "formal" de estas "leyes constitucionales" obvia que el procedimiento de elaboración de ambos tipos de leyes y la mayoría requerida para su aprobación (mayoría simple) es la misma.

A pesar de éstas, a mi entender, incoherencias, lo cierto es que en 2012 varios jueces del Tribunal Supremo asumieron la categoría de las "leyes constitucionales" pero para aplicarla a la ley que establece la autonomía de Escocia (Scotland Act). ${ }^{41}$ Sin embargo, dos años después, el UKSC, reconociendo que en el Reino Unido no existe una "Constitución escrita", y aun afirmando que existen una serie de "instrumentos constitucionales" 42

implied repeal does not satisfy this test. Accordingly, it has no application to constitutional statutes").

40 (2002) EWHC 195 (Admin), Thoburn v. Sunderland City Council, parágrafo 69 ("The ECA is a constitutional statute: that is, it cannot be impliedly repealed").

41 (2012) UKSC 24, BH (AP) (Appellant) and another $v$ The Lord Advocate and another (Respondents) (Scotland), de 20 de junio de 2012, Opinión de Lord Hope (a la que concurren Lady Hale y Lord Kerr), para. 30 ("It would perhaps have been open to Parliament to override the provisions of section 57(2) so as to confer on them more ample powers than that subsection would permit in the exercise of their functions under the 2003 Act. But in my opinion only an express provision to that effect could be held to lead to such a result. This is because of the fundamental constitutional nature of the settlement that was achieved by the Scotland Act. This in itself must be held to render it incapable of being altered otherwise than by an express enactment. Its provisions cannot be regarded as vulnerable to alteration by implication from some other enactment in which an intention to alter the Scotland Act is not set forth expressly on the face of the statute").

42 (2014) UKSC 3, HS2 Action Alliance Ltd, R (on the application of) v The Secretary of State for Transport \& Anor, del 22 de enero de 2014, paraágrafo 207 ("The United Kingdom has no written constitution, but we have a number of constitutional instruments. They include Magna Carta, the Petition of Right 1628, the Bill of Rights and (in Scotland) the Claim of Rights Act 1689, the Act of Settlement 1701 and the Act of Union 1707. The European Communities Act 1972, the Human Rights Act 1998 and the Constitutional Reform Act 2005 may now be added to this list. The common law itself also recognises 
Esta revista forma parte del acervo de la Biblioteca Jurídica Virtual del Instituto de Investigaciones Jurídicas de la UNAM

muestran una sutil reserva ante la existencia de la categoría de las "leyes constitucionales" como muestra, creo el hecho de que entrecomillen las denominaciones que diferencian entre leyes "constitucionales" y leyes "ordinarias". Por lo demás, en el caso de autos, el UKSC afirma que no se da un conflicto entre leyes "constitucionales" y "ordinarias", sino entre dos "instrumentos constitucionales". ${ }^{43}$

\section{PERSPECTIVAS EN LA ORGANIZACIÓN DEL PODER DEL SISTEMA POLÍTICO BRITÁNICO}

Se puede afirmar que el proceso que ha producido unas transformaciones tan sustanciales en el régimen político británico ha comenzado con la incorporación del Reino Unido a las Comunidades Europeas en 1972. La salida de este país de la Unión Europea en 2020, casi cincuenta años después, plantea la cuestión de en qué medida estos cambios pueden ser reversibles. El hecho de que la configuración del régimen político británico no esté formalizada en un instrumento jurídico rígido (Constitución escrita) del mismo modo que contribuyó a facilitar esas transformaciones, que dificilmente pudieron haber sido planificadas, ¿podría igualmente facilitar una reversión del proceso evolutivo del sistema político?

En el proceso de lucha por el poder dentro del sistema británico parece claro, en primer lugar, que al menos hasta 2019, el Ejecutivo (Gabinete) ha perdido peso. Parece igualmente claro, en segundo lugar, que el gran ganador en el proceso ha sido el Poder Judicial y, en particular, el Tribunal Supremo creado en estos últimos años. En tercer lugar, se aprecia que el Parlamento también ha mejorado su posición, al garantizar su permanen-

certain principles as fundamental to the rule of law. It is, putting the point at its lowest, certainly arguable (and it is for United Kingdom law and courts to determine) that there may be fundamental principles, whether contained in other constitutional instruments or recognised at common law, of which Parliament when it enacted the European Communities Act 1972 did not either contemplate or authorise the abrogation").

43 (2012) UKSC 24, BH (AP) (Appellant) and anotherv The Lord Advocate and another (Respondents) (Scotland), para, 208 ("Important insights into potential issues in this area are to be found in their penetrating discussion by Laws LJ in the Divisional Court in Thoburn $v$ Sunderland City Council [2002] EWHC 195 (Admin), [2003] QB 151, (The Metric Martyrs case), especially paras 58-70, although the focus there was the possibility of conflict between an earlier "constitutional" and later "ordinary" statute, rather than, as here, between two constitutional instruments, which raises yet further considerations"). 
Esta revista forma parte del acervo de la Biblioteca Jurídica Virtual del Instituto de Investigaciones Jurídicas de la UNAM

cia frente a una posible disolución y una injustificada suspensión por obra del jefe del Ejecutivo, beneficiándose de algunas legislaturas en las que el Gabinete no tenía garantizada una mayoría absoluta. Y, por si fuera poco, en cuarto lugar, ha emergido como actor político el "pueblo" merced al referéndum de 2016.

Pero la intensidad de los enfrentamientos políticos que se han vivido en el Reino Unido y la dimensión de los cambios producidos sugieren que esta lucha por el poder no ha terminado, aunque sólo fuera porque el, hasta ahora, gran perdedor (el Ejecutivo) quiera recuperar su poder. La mayoría absoluta de Boris Johnson, tras las elecciones del 12 de diciembre de 2019, parece presagiar una etapa jurídico-política más tranquila que la convulsa legislatura anterior. Ciertamente, todo parece indicar que se va a poner fin a la pugna entre el Ejecutivo y el Parlamento y que el Ejecutivo recuperará algunos de los poderes que le arrebató el Parlamento. Prueba de ello es la "Ley del Acuerdo de Retirada del Reino Unido de la Unión Europea" aprobada el 23 de enero de 2020, poco más de un mes después de celebradas las elecciones de diciembre de 2019, que ha eliminado la necesidad de que la negociación del Ejecutivo británico con el Ejecutivo europeo para retirarse de la organización europea tenga que ser validada por el Parlamento. ${ }^{44}$

¿Qué posibles escenarios tendrá esa lucha de continuar en el futuro próximo? A mi entender son varios los posibles escenarios.

El primero, probable, es que tras la mayoría absoluta conservadora en el Parlamento surgido de las elecciones del 12 de diciembre de 2019 pudiera llegar a plantearse la derogación de la "Ley de las Legislaturas Fijas del Parlamento" para devolver al primer ministro el poder de disolver la Cámara de los Comunes. De esta forma el Ejecutivo recuperaría parte del poder perdido en beneficio del Parlamento. La transferencia del peso político del Parlamento al Ejecutivo sólo quedará formalizada si se derogase la "Ley de las Legislaturas Fijas del Parlamento". Un año después de las elecciones de 2019, parecen confirmarse estas previsiones pues el gobierno británico ha presentado un proyecto de ley que deroga la "Ley

44 European Union (Withdrawal Agreement) Act 2020 (c. 1). An Act to implement, and make other provision in connection with, the agreement between the United Kingdom and the EU under Article 50(2) of the Treaty on European Union which sets out the arrangements for the United Kingdom's withdrawal from the EU. Section 31. 
Esta revista forma parte del acervo de la Biblioteca Jurídica Virtual del Instituto de Investigaciones Jurídicas de la UNAM

de las Legislaturas Fijas del Parlamento" (artículo 2o. del proyecto) y prohíbe explícitamente que el ejercicio de la prerrogativa regia de disolver el Parlamento pueda ser cuestionado ante los tribunales de justicia (artículo 3o. del proyecto). ${ }^{45}$

El segundo escenario, creo que poco probable, es que el Ejecutivo promueva en el Parlamento la derogación de la "Ley de la Reforma Constitucional" de 2005, para eliminar el Tribunal Supremo, aunque ahora resultaría bastante conflictivo restituir el Tribunal de los Lores jueces, aparte de que sería ignorar que grandes cambios en el derecho inglés se han producido (casos Factortame) en virtud de sentencias dictadas por el Tribunal de los Lores. Sería éste, sin duda, un cambio de gran calado que permitiría disminuir el de los tribunales y restituirlo al Parlamento y al Ejecutivo. Sin embargo, las alteraciones del sistema de poder producidas tras la pugna del Ejecutivo con el Poder Judicial, con la judicialización del Brexit serán de muy difícil reversión en un sistema que da tanta importancia al "precedente" judicial.

En tercer lugar, parece que es difícil que desaparezca la categoría de las "leyes constitucionales" en tanto en cuanto es una categoría creada por el Poder Judicial y no por el Parlamento mismo o el Gabinete. Ahora bien, esta categoría ha perdido buena parte de su sentido una vez que el Reino Unido se ha retirado de la Unión Europea y el derecho comunitario ha dejado de ejercer, aunque fuera en ámbitos restringidos, su "primacía" sobre el derecho nacional. A este respecto no deja de ser profundamente significativo que en la ley de retirada de la Unión Europea de 2020 haya incluido un artículo para reafirmar, explícitamente, la "soberanía del Parlamento". ${ }^{46}$

Finalmente, un cuarto escenario, creo que altamente improbable, sería que el Ejecutivo intentara disminuir el poder del Parlamento y de la Judicatura oponiéndoles el contrapoder del "pueblo". Para empezar, el Gabinete no tendría necesidad de disminuir el poder del Parlamento si la

45 Draft Fixed-term Parliaments Act 2011 (Repeal) Bill. Presented to the House of Commons by the Chancellor of the Duchy of Lancaster and Minister for the Cabinet Office, and the Minister for the Constitution and Devolution. Presented to the House of Lords by the Minister of State for the Cabinet Office by Command of Her Majesty. December 2020.

46 European Union (Withdrawal Agreement) Act 2020 (c. 1). Section 38.1 "It is recognised that the Parliament of the United Kingdom is sovereign". 
Esta revista forma parte del acervo de la Biblioteca Jurídica Virtual del Instituto de Investigaciones Jurídicas de la UNAM

mayoría permanece fiel al primer ministro. Es cierto que, aunque ahora el Ejecutivo esté confortado por una amplia mayoría parlamentaria, podría tener la tentación de introducir esta variable como mecanismo "preventivo" en la eventualidad de que pudiera volver a repetirse la situación del Parlamento de la Legislatura 2017-2019. Esta apuesta "populista" ofrecería la paradoja de ver cómo un grupo de políticos extraídos de las capas más elitistas (Eton, Oxford) liquidarían el sistema (la "soberanía del parlamento") que garantizó durante siglos el poder de las elites. Sin embargo, como se ha visto, después de haber invocado la voluntad del "pueblo" para hacer que se ejecutara el "Brexit"... la redacción de 2020 de la Ley de Retirada de la Unión Europea parece que cierra la puerta a la "soberanía del pueblo" al reafirmar, como hemos visto, la "soberanía del Parlamento".

\section{BIBLIOGRAFÍA}

BISGARETTI DI RUFFIA, Paolo. 1996. Introducción al derecho constitucional comparado. México. Fondo de Cultura Económica.

BRYCE, James. 1901. "Flexible and rigid Constitutions". Studies in History and Furisprudence, vol. 1. Nueva York. Oxford University Press, 124-213 (existe traducción española de Nicolás Ramiro Rico. 1952. Constituciones flexibles y Constituciones rígidas. Madrid. Instituto de Estudios Políticos).

Burgess, Juan W. 1897. Ciencia politica y derecho constitucional comparado, 2 vols. Madrid. La España Moderna.

DiCEY, Albert Venn. 1885. Introduction to the Study of the Law of the Constitution. Londres. Macmillan and Co.

FiX-Zamudio, Héctor y Valencia Carmona, Salvador. 2012, Derecho constitucional mexicano y comparado. 8a. ed. México. Porrúa-UNAM.

GARCÍA DE ENTERRÍA MARTíNEZ-CARANDE, Eduardo. 1962. "La lucha contra las inmunidades del poder en el derecho administrativo (poderes discrecionales, poderes de gobierno, poderes normativos)". Revista de Administración Pública 38: 159-208.

García de EnTERría Martínez-Carande, Eduardo. 1998. "El fin del caso Factortame: la responsabilidad patrimonial final del Reino Unido". Revista de Administración Pública 14: 117-144. 
Esta revista forma parte del acervo de la Biblioteca Jurídica Virtual del Instituto de Investigaciones Jurídicas de la UNAM

GonZÁlez García, Teodoro. 1927. La soberanía del Parlamento inglés: su evolución política, su estado actual. Murcia. Sucesores de Nogués.

GonzÁlez García, Teodoro. 1945. Desviaciones políticas en la Gran Bretaña. Discurso leído en la solemne apertura del curso académico 1946-1947. Valladolid. Universidad de Valladolid.

GonzÁlez García, Teodoro. 1950. El rumbo de la Gran Bretaña: de la era victoriana al gobierno laborista. Valladolid. Universidad de Valladolid.

GonzÁlez GarcíA, Teodoro. 1955. "La corona británica". Revista de la Facultad de Derecho de la Universidad de Oviedo 72, 37-78.

Lolme, Jean-Louis de. 1807. The Constitution of England; Or, An Account of the English Government; In which it is Compared both with the Republican Form of Government, and the Other Monarchies in Europe. A new edition; with supplemental notes, and a preface biographical and critical. Londres. G. Wilkie and J. Robinson.

MILLER, Vaughne. 2015. "The 1974-75 UK Renegotiation of EEC Membership and Referendum. Briefing Paper, 7253. Londres. House of Commons Library.

SÁnCHEZ Agesta, Luis. 1968. Curso de derecho constitucional comparado. Madrid. Editora Nacional.

Vírgala FORURIA, Eduardo. 2019. La Constitución británica en el siglo XXI. Soberanía parlamentaria, constitucionalismo common law y leyes constitucionales. Madrid. Marcial Pons. 